\title{
DUALISME PEMBATALAN PERATURAN DAERAH PROVINSI DENGAN PERATURAN PRESIDEN DAN PERATURAN MENTERI DALAM NEGERI \\ Oleh:
}

\section{Gde Edi Budiputra ${ }^{1}$}

\begin{abstract}
Local regulations are local regulations that are established by local specificities recognized by the Constitution of the Republic of Indonesia-1945 as part of their decentralization. Local regulations can not contradict the legislation of higher order not to cause a result of the cancellation. This cancellation is the authority of the central government in relation to the unitary state. Supervision by the central government there are two models of preventive supervision and oversight repesif. Cancellation regulatory oversight repesif area is conducted on local government. Cancellation Provincial Regulation made by the President and the Minister of the Interior gave rise to a dualism. For it will be discussed on How cancellation arrangements are made with the Provincial Regulations and Regulations Presidential Decree of the Minister of the Interior? 2. What is the legal effect of the cancellation of Provincial Regulation by Presidential Decree and the Regulation of the Minister of the Interior? The issues discussed using normative research by using the approach of legislation, the legal concept analysis approach, in order to obtain answers that dualism cancellation provincial regulations stipulated in several laws including Law No. 32 Year 2004 on Regional Government, Law No. 28 year 2009 on Local Taxes and levies, Government Regulation No. 79 Year 2005 on Guidelines Direction and Control of Local Government, Minister of the Interior No. 1 Year 2014 on the Establishment of the Regional law Products stating that the authority of the cancellation of regulations made by the President of the instrument while the Presidential Decree cancellation made by the Minister of the Interior was limited to cancellation Draft Regional Regulation on stage during the evaluation of preventive supervision and legal consequences caused by the dualism cancellation of local regulations are different between cancellation made by the President and minister of Interior. Cancellation is cancellation of its President in the field of executive interim final cancellation made by the Minister of the Interior if the local government to enforce the local regulations canceled Interior Minister will ask the cancellation to the President.
\end{abstract}

Keywords: Dualism, Regional Regulation, Supervision, and Cancellation.

Mahasiswa Magister Ilmu Hukum Universitas Udayana, Denpasar,Bali. Alamat Jl. Untung Surapati, GG. Nusa Indah-Amlapura BTN Dalung permai Blok BB 58.Denpasar, e-mail : edigordo_d1@yahoo.com 


\section{PENDAHULUAN}

\section{I.1. Latar Belakang Masalah}

Pada Pasal 18 ayat (1) Undang-Undang Dasar Negara Republik Indonesia Tahun 1945 (selanjutnya disingkat UUDNRI Tahun 1945)menyatakan Negara Kesatuan Republik Indonesia dibagi atas daerah-daerah provinsi dan daerah provinsi itu dibagi atas kabupaten dan kota, yang tiap-tiap provinsi, kabupaten, dan kota itu mempunyai pemerintahan daerah, yang diatur dengan undangundang. Pada pasal ini juga menekankan pemerintah diwajibkan melaksanakan asas desentralisasi, dekonsentrasi dan tugas pembantuan yang semuanya diatur dengan Undang-Undang organik. ${ }^{2}$ Salah satunya adalah Undang-undang No. 32 Tahun 2004 Tentang Pemerintahan Daerah, yang telah diganti dan dicabut dengan Undang-undang No. 23 Tahun 2014 Tentang Pemerintahan Daerah (Lembaran Negara Republik Indonesia Tahun 2014 Nomor 244, Tambahan Lembaran Negara Republik Indonesia Nomor 5587), (selanjutnya disingkat UU No. 23 Thn 2014).

Dengan adanya suatu pengakuan serta pengaturan yang secara khusus mengatur tentang pemerintahan daerah dan sebagai suatu daerah otonom terutama pengakuan terhadap pemerintahan daerah provinsi maka untuk itu diperlukan adanya suatu aturan yang secara khusus mengatur daerah yang mempertimbangkan kekhususan

Soehino, 1991, Hukum Tata Negara Perkembangan Otonomi Daerah, Yogyakarta, Edisi Pertama, Cetakan Pertama, BPFE, h. 16. yang menjadikan daerah memiliki payung hukum untuk memngembangkan daerah berdasarkan pada potensi yang dimiliki suatu daerah serta memberikan legitimit tindakan yang dilakukan oleh pemerintah daerah dalam rangka memajukan serta memberikan payung hukum tindakan pemerintah daerah. Peraturan ini tentunya adalah Peraturan Daerah (Perda), sebagai produk legislatif daerah. Perda sebagai produk hukum di daerah, hendaknya mampu mengarahkan masyarakat daerah ke arah yang lebih baik dan mampu mengayomi masyarakat.

Mengingat perda merupakan salah satu jenis hirarki peraturan perundang-undangan sebagaimana tertuang pada Undang-Undang No. 12 Tahun 2011 Tentang Pembentukan Peraturan Perundang-undangan (Lembaran negara Republik Indonesia Tahun 2011 Nomor 82, Tambahan Lembaran Negara Republik Indonesia Nomor 5234), (selanjutnya disingkat UU PPPU) Pasal 7 ayat (1) Perundang-undangan terdiri atas:

a. Undang-Undang Dasar Negara Republik Indonesia Tahun 1945;

b. Ketetapan Majelis Permusyawaratan Rakyat;

c. Undang-Undang/PeraturanPemerintah Pengganti Undang-Undang;

d. Peraturan Pemerintah;

e. Peraturan Presiden;

f. Peraturan Daerah Provinsi; dan

g. Peraturan Daerah Kabupaten/Kota.

Maka dalam pembentukannya pun harus menyesuaikan dengan pengaturan mengenai materi muatan seperti halnya Undang-undang sebagaimana yang diatur 
pa Pasal 14 UU PPPU menentukan materi muatan Peraturan Daerah Provinsi dan Peraturan Daerah Kabupaten/Kota berisi materimuatan dalamrangka penyelenggaraan otonomi daerah dan tugas pembantuan serta menampung kondisi khusus daerah dan/atau penjabaran lebih lanjut Peraturan Perundangundangan yang lebih tinggi.

Pengawasan yang dilakukan oleh Pemerintah Pusat kepada Pemerintah Daerah terdapat dua bentuk yakni, pengawasan preventif dan pengawasan represif. Pengawasan preventif melalui tahap evaluasi kepada Rencana Perda (Ranperda) Anggaran Pendapatan Belanja Daerah (APBD), pajak daerah dan retribusi daerah serta Peraturan Daerah Tata Ruang kini ditambah dengan Rencana Pembangunan Jangka Panjang Daerah yang selanjutnya disingkat RPJPD, Rencana Pembangunan Jangka Menengah Daerah yang selanjutnya disingkat RPJMD, serta penambahan terhadap Pembatalan yang menjadi kewenangan Gubernur apabila Gubernur tidak melaksanakannya kemudian akan diambil alih oleh Menteri Dalam Negeri serta keberatan pembatalan yang dilakukan Gubernur terhadap Kabupaten/ Kota dilakukan oleh Pemerintah dalam hal ini adalah Menteri Dalam Negeri. Sementara pengawasan represif dilakukan oleh Pemerintah terhadap seluruh Peraturan Daerah Provinsi dan Kabupaten/Kota yang pada dasarnya sesudah dilakukannya pengawasan preventif.

Adanya Pasal 145 ayat (3) UU No. 32 Thn 2004 Keputusan pembatalan Perda sebagaimana dimaksud pada ayat (2) ditetapkan dengan Peraturan Presiden paling lama 60 (enam puluh) hari sejak diterimanya Perda sebagaimana dimaksud pada ayat (1). Kewenangan Presiden dalam membatalkan perda dengan instrumen Peraturan Presiden (Perpres) serta dengan adanya kewenangan Mendagri yang diatur pada Pasal 185 UU No. 32 Thn 2004 dan Pasal 251 UU No. 23 Thn 2014 merupakan kewenangan dalam kaitannya proses evaluasi Ranperda dengan pengawasan secara preventif, tetapi dengan adanya Pasal 90 ayat (3) dan (4) Permendagri 1 Thn 2014 yang menyatakan Hasil klarifikasi Perda sebagaimana dimaksud pada ayat (2), apabila tidak sesuai dengan hasil evaluasi maka Perda dimaksud dibatalkan oleh Menteri Dalam Negeri. Hal ini menimbulkan dualisme Pembatalan Peraturan Daerah provinsi.

Dalam pembatalan perda berkaitan pengawasan secara represif terdapat dua model pembatalannya yang dilakukan oleh pemerintah pusat.

1. Pembatalan oleh Presiden dengan Peraturan Presiden terhadap seluruh perda tanpa terkecuali.

2. Pembatalan oleh Menteri Dalam Negeri dengan Peraturan Menteri Dalam Negeri pada tahap klarifikasi bentuknya sudah Perda APBD, Pajak daerah dan retribusi daerah dan perda tata ruang provinsi serta penambahan terhadap RPJPD dan RPJMD serta pembatalan Perda Kabupaten/Kota yang tidak dibatalkan oleh Gubernur serta keberatan Pemerintah Kabupaten/ Kota terhadap Perda yang dibatalkan oleh Gubernur. 
Berdasarkan latar belakang masalah yang telah penulis ungkapkan sebelumnya, maka penulis tertarik untuk meneliti masalah hukum ini dalam bentuk jurnal ilmiah yang berjudul: "DUALISME PEMBATALAN PERATURAN DAERAH PROVINSI DENGAN PERATURAN PRESIDEN DAN PERATURAN MENTERI DALAM NEGERI'.

\section{I.2. Rumusan Masalah}

Berdasarkan pemaparan latar belakang masalah yang telah diungkapkan sebelumnya, rumusan masalah yang akan dibahas pada penelitian ini yakni berkaitan dengan :

1. Bagaimanakah pengaturan pembatalan Perda Provinsi yang dilakukan dengan Peraturan Presiden dan Peraturan Menteri Dalam Negeri?

2. Apakah akibat hukum pembatalan Perda dengan Peraturan Presiden dan Peraturan Menteri Dalam Negeri?

\section{Tujuan Penelitian}

Tujuan daripada penelitian ini dimaksudkan untuk mengetahui adanya dualisme Pembatalan Perda Provinsi yang dilakukan oleh Presiden dengan instrumen Peraturan Presiden dan Menteri Dalam Negeri dengan instrumen Peraturan Menteri Dalam Negeri. Sehingga memberikan penjelasan pejabat dan bentuk pembatalan perda itu sendiri, dengan harapan semua daerah memiliki pemahaman bahwa perda yang dibentuk oleh pemerintah daerah tidaklah diawasi oleh oleh pemerintah pusat

A. Muktie Fajar dan Yulianto Ahmad, 2009, Dualisme Penelitian Hukum Normatif dan Empiris, Pustaka Pelajar, Yogyakarta. h. 153. sekalipun pemerintah daerah memiliki kewenangan untuk membentuk perda juga memberikan penjelasan bahwa daerah juga dapat mengajukan perlawan dengan mengajukan suatu keberatan terhadap pembatalan perda.

\section{Metode Penelitian}

Pada penelitian ini merupakan suatu jenis penelitian normatif yang dimana penelitian hukum normatif, yang mencakup penelitian terhadap asas-asas hukum, penelitian terhadap sistematika hukum, penelitianterhadaptarafsinskronisasihukum, penelitian sejarah hukum, dan penelitian perbandingan hukum. ${ }^{3}$ Salah satunya adalah sinkronisasi hukum akibat adanya dualisme pembatalan perda yang dilakukan oleh pemerintah pusat dengan Peraturan Presiden dan Peraturan Menteri Dalam Negeri. Pada penelitian ini mempergunakan pendekatan Pendekatan yang dipergunakan dalam penelitian ini adalah pendekatan perundang-undangan, Pendekatan kasus (cases approach), dan Pendekatan analisis konsep hukum (Analitical and Conceptual Approach). Dengan mempergunakan bahan hukum primer, bahan hukum sekunder dan bahan hukum tertier yang dikumpulkan mempergunakan teknik kartu dan snowball method, yang selanjutnya dianalisis teknik deskripsi, teknik argumentasi, teknik sistematisasi. 


\section{HASIL DAN PEMBAHASAN}

\section{a. Pengaturan Pembatalan Perda}

Provinsi Yang Dilakukan Dengan

Peraturan Presiden dan Peraturan

\section{Menteri Dalam Negeri}

Konsepsi pemerintahan daerah bukanlah dalam artian sebuah lembaga, melainkan menunjuk pada tempat proses penyelenggaraan urusan atau tugas negara, yakni di daerah sebagai perpanjangan penyelenggaraan pemerintahan oleh Pemerintah Pusat. ${ }^{4}$ Setelah lahirnya otonomi daerah, dalam rangka untuk menampung aspirasi masyarakat di daerah, kepentingan umum dalam penafsirannya harus disesuaikan dengan masyarakat setempat, sikap pemerintah tidak dibenarkan secara parsial memihak bagi golongan tertentu saja, tetapi dilakukan secara menyeluruh untuk kepentingan masyarakat. ${ }^{5}$

Salah satu prinsip penyelenggaraan pemerintahan di daerah adalah untuk meningkatkan dayaguna dan hasilguna penyelenggaraan

pemerintahan, terutama dalam tujuan otonomi derah yakni pelaksanaan pembangunan dan layanan terhadap masyarakat serta untuk meningkatkan pembinaan kestabilan politik dan kesatuan bangsa. ${ }^{6}$ Hubungan pusat dan daerah yaitu dalam hal pengawasan. Secara terminologis istilah pengawasan disebut juga dengan istilah controlling, evaluating, appraising, correcting maupun control. ${ }^{7}$

Peraturan daerah yang menyimpang dari hukum dapat setiap saat dibawakan ke Mahkamah Agung untuk dapat dinyatakan tidak mengikat secara hukum oleh Mahkamah Agung. ${ }^{8}$ Pengendalian pemerintah pusat terhadap daerah melalui instrumen pengawasan, yang baik langsung maupun tidak langsung telah menyeret fungsi pemerintah sebagai badan eksekutif masuk ke ranah fungsi yudisial yang lazimnya menjadi otoritas badan yudikatif. ${ }^{9}$

Telah banyak peraturan daerah yang dibatalkan, pembatalan ini dikarenakan seperti yang tertuang dalam Pasal 136 ayat (4) UU No. 32 Thn 2004 lama, Perda sebagaimana dimaksud pada ayat (1) dilarang bertentangan dengan kepentingan umum dan/atau peraturan perundangundangan yang lebih tinggi. Mengenai bertentangan dengan peraturan perundangundngan yang lebih tinggi seperti Undangundang/Peraturan Pemerintah Pengganti Undang-undang, Peraturan Pemerintah dan Peraturan Presiden. Berkaitan dengan bertentangan dengan kepentingan umum berdasarkan Penjelasan Pasal 136 ayat (4) UU No. 32 Thn 2004 adalah kebijakan

Pustaka Sutra, Denpasar, h. 37.
Adrian Sutedi, 2007,Implementasi Prinsip Kepentingan Umum Dalam Pengadaan Tanah Untuk Pembangunan, Sinar Grafika, Jakarta, h. 49.

H. A. W. Widjaja, 2005, Penyelenggaraan Otonomi di Indonesia, Dalam Rangka Sosialisasi UndangUndang No. 32 Tahun 2004 Tentang Pemerintahan Daerah, PT. Raja Grafindo Persada, Jakarta, h. 208.

\footnotetext{
Muh Fauzan, 2006, Hukum Pemerintahan Daerah
Kajian Tentang Hubungan Keuangan Antara Pusat

Muh Fauzan, 2006, Hukum Pemerintahan Daerah
Kajian Tentang Hubungan Keuangan Antara Pusat Dan Daerah, UII Press, Yogyakarta, h. 90. Jimly Asshiddiqie, 2006, Hukum Acara Pengujian Undang-Undang, Konstitusi Press, Jakarta, h. 38.

9 Widodo Ekathahjana, 2008, Pengujian Peraturan Perundang-Undangan Dan Sistem Peradilannya di Indonesia, Pustaka Sutra, Jakarta, h. 37.
} 
yang berakibat terganggunya kerukunan antar warga masyarakat, kebijakan yang berakibat terganggunya pelayanan umum, dan kebijakan yang berakibat terganggunya ketentraman/ketertiban umum serta kebijakan yang bersifat diskriminatif. Pada UU No. 23 Thn 2014 Pasal 250

Perda dan

Perkada sebagaimana dimaksud dalam Pasal 249 ayat (1) dan ayat (3) dilarang bertentangan dengan ketentuan peraturan perundangundangan yang lebih tinggi, kepentingan umum, dan/atau kesusilaan.

(2) Bertentangan dengan kepentingan umum sebagaimana dimaksud pada ayat (1) meliputi:

a. terganggunya kerukunan antarwarga masyarakat;

b. terganggunyaakses terhadap pelayanan publik;

c. terganggunya ketenteraman dan ketertiban umum;

d. terganggunya kegiatan ekonomi untuk meningkatkan kesejahteraan masyarakat; dan/atau

e. diskriminasi terhadap suku, agama dan kepercayaan, ras, antar-golongan, dan gender.

Pengawasan terhadap segala tindakan pemerintahan daerah, termasuk juga produk hukum daerah menurut sifatnya digolongkan menjadi :

1. Pengawasan umum

2. Pengawasan preventif

3. Pengawsan represif. ${ }^{10}$

10 Irawan Soetjito, 1993, Pengawasan terhadap Peraturan Daerah dan Keputusan Kepala Daerah, Bina Aksara, Jakarta, h. 11
Pembatalan peraturan Daerah yang diatur pada No. 32 Thn 2004, Pasal 145 UU merupakan kewenangan Presiden untuk membatalkan Perda yang merupakan tindakan dalam rangka pengawasan secara represif. Ketentuan Pasal 185 memberi wewenang kepada Menteri Dalam Negeri membatalkan Raperda Provinsi tentang APBD dan Peraturan Gubernur tentang Penjabaran APBD yang bertentangaran dengan kepentingan umum atau perataturan perundang-undangan yang lebih tinggi setelah Gubernur tidak mengindahkan hasil evaluasi. Jika membedah UU No. 32 Thn 2004 sebagai dasar pembatalan perda maka yang akan dapat ditemukan dalam UU No. 32 Thn 2004 ini adalah :

1. Mengatur mengenai pembatalan perda provinsi dengan instrumen hukum pembatalannya adalah Peraturan Presiden terhadap seluruh Perda baik Perda Provinsi maupun Perda Kabupaten/Kota kecuali Perda APBD, Perda pajak daerah dan retribusi daerah dan perda RTRW, Provinsi maupun Kabupaten/Kota, sebagaimana yang diamanatkan pada Pasal 145.

2. Mengatur mengenai pembatalan Raperda Provinsi terbatas pada Raperda APBD, Pajak daerah dan retribusi daerah dan RTRW dengan melalui tahap evaluasi terlebih dahulu oleh Mendagri, sebagaimana yang dimaksud pada Pasal 185, dengan instrumen hukumnya yakni Peraturan Menteri Dalam Negeri. 
3. Mengatur mengenai pembatalan Raperda Kabupaten/Kota terbatas pada Raperda APBD, Pajak daerah dan retribusi daerah dan RTRW dengan melalui tahap evaluasi terlebih dahulu oleh Gubernur sebagaimana yang dimaksud pada Pasal 186.

Diundangkannya UU No. 23 Thn 2014 Tentang Pemerintahan Daerah maka dengan itu UU No. 32 Thn 2004 Tentang Pemerintahan Daerah tidak berlaku kembali, oleh karenanya aturan-aturan mengenai pemerintahan daerah yang masih mengacu pada UU No. 32 Thn 2004 harus menyesuaikan kepada UU No. 23 Thn 2014. Terdapat perbedaan dan persamaan pengaturan mengenai pembatalan perda yang diatur pada masing-masing Undangundang tersebut.

Pasal 245 ini menentukan bahwa Menteri Dalam Negeri memiliki kewenangan dalam rangka mengevaluasi Ranperda Provinsi yang mengatur tentang RPJPD, RPJMD, APBD, perubahan APBD, pertanggungjawaban pelaksanaan APBD, pajak daerah, retribusi daerah dan tata ruang daerah, yang mana terdapat penambahan yakni berkaitan dengan RPJPD dan RPJMD yang pada UU No. 32 Thn 2004 tidak diatur.

Pasal 251 dengan tegas menjabarkan kewenangan Menteri Dalam Negeri yang berkaitan dengan pembatalan perda provinsi serta perda kabupaten/kota apabila Gubernur yang memiliki kewenangan untuk membatalkan perda tersebut tidak melakukan pembatalan. Mendagri juga memiliki kewenangan untuk menerima keberatan penyelenggara Kabupaten/Kota terhadap pembatalan Perda yang dilakukan ileh Gubernur, kewenangan Mendagri ini sangatlah lebih besar jika dibandingkan saat pengaturanya pada UU No. 32 Thn 2004.

Pembatalan terhadap Ranperda RPJPD dan RPJMD Provinsi merupakan kewenangan baru yang dimiliki Mendagri sebagaimana yang diatur pada Pasal 267-269 UU No. 23 Thn 2014 karena sebelumnya pada UU No. 32 Thn 2004 pengaturan pembatalan Ranperda ini tidak pernah ada.

Ketentuan mengenai Pasal 314 dan 324 UU No. 23 Thn 2014 merupakan kewenangan Mendagri dalam melakukan evaluasi terhadap APBD yang diajukan oleh Gubernur, serta Pajak Daerah dan Retribusi Daerah seperti halnya yang terdapat pada UU No. 32 Thn 2004 pada saat evaluasi dilakukan oleh Mendagri pembatalannya sifatnya masih preventif.

Peraturan Pemerintah No. 79 Thn 2005 mengatur mengenai pejabat yang memiliki kewenangan pembatalan Perda, bentuk hukum pembatalan perda dan produk hukum daerah yang dibatalkan. Lebih lanjut pengaturan mengenai pembatalan Perdadapat dijumpai pada Pasal 37 sampai dengan Pasal 42.Mendagri dapat membatalkan Raperda Provinsi yang diajukan oleh Gubernur untuk Raperda APBD, Pajak daerah dan Retribusi daerah dan RTRW setelah melalui tahapan evaluasi dan membatalakan Perda Provinsi berkaitan dengan APBD, Pajak Daerah dan Retribusi daerah dan RTRW setelah melalui tahapan Klarifikasi melalui Peraturan Menteri 
Permendagri 1 Tahun 2014 mengatur sebagai berikut:

1. Istilah pengawasan represif yang telah lazim disebutkan sebagai pengawasan setelah sahnya peraturan diganti dengan istilah klarifikasi.

2. Wewenang melaksanakan klarifikasi terhadap Peraturan Daerah Kabupaten/ Kota dan Peraturan Bupati/ Wlikota yang sebelumnya menurut PP No. 79 Thn 2005 merupakan wewenang Mendagri, dilimpahkan kepada Gubernur.

Berdasarkan pengaturan pada Pasal 76 sampai dengan Pasal 80 Permendagri No. 1 Thn 2014 merupakan pengaturan mengenai tahapan evaluasi Raperda Provinsi berkaitan dengan APBD, Pajak daerah dan Retribusi daerah yang dievaluasi oleh Mendagri dengan berkoordinasi dengan Menteri keuangan dan Perda RTRW oleh Menteri Dalam Negeri dengan berkoordinasi dengan Menteri yang membidangi urusan tata ruang. Apabila hasil evaluasi menunjukan penolakan terhadap raperda yang diajukan oleh Gubernur Menteri Dalam Negeri membatalkan Perda dan Peraturan Gubernur dengan Peraturan Menteri.

Pengaturan Klarifikasi sebagai bentuk pengawasan represif pemerintah pusat kepada pemerintah daerah untuk Provinsi untuk Perda APBD, pajak daerah dan retribusi daerah dan RTRW hasil klarifikasi dapat berbentuk persetujuan bahwa Perda Provinsi dinyatakan tidak bertentangan dengan kepentingan umum dan peraturan perundang-undangan yang lebih tinggi atau perda provinsi tersebut dinyatakan bertentangan dengan kepentingan umum dan peraturan perundang-undangan yang lebih tinggi yang selanjutnya Mendagri membatalkan Perda Provinsi tersebut dengan Peraturan Mendagri dan meminta daerah untuk melakukan penyempurnaan dan/ atau mencabut perda yang telah dibatalkan tersebut. Akan tetapi jika pemerintah daerah tidak mengindahkan hasil klarifikasi dan tetap menetapkannya menjadi Perda maka Mendagri akan meminta kepada Presiden untuk membatalkan Perda tersebut.

\section{b. Akibat Hukum Pembatalan Perda Dengan Peraturan Presiden Dan Peraturan Menteri Dalam Negeri}

Kewenangan dalam arti yuridis yang diberikan oleh peraturan perundangundangan yang berlaku untuk menimbulkan akibat-akibat hukum. ${ }^{11}$ Seperti yang kita ketahui atribusi delegasi dan mandat merupakan sumber kewenangan yang penting dalam negara demokrasi yang salah satu asasnya menekankan tindak pemerintahan harus didasarkan atas hukum. Asas demikian lazimnya disebut asas legalitas atau Rechtmatigheid van bestuur. ${ }^{12}$

Berbicara mengenai pembatalan merupakan suatu tindakan hukum pemerintahan yang memberikan akibat hukumsertamenimbulkanhak dankewajiban. Pembatalan Perda Provinsi yang sifatnya

\footnotetext{
Indrohato, 1991, Usaha Memahami UndangUndangTentang Peradilan tata Usaha Negara, Pustaka Sinar Harapan, Jakarta, h. 68.

12 SF. Marburn, 1997, Peradilan Administrasi Negara dan Upaya Administrasi di Indonesia, Liberty, Yogyakarta, h. 158.
} 
represif bukan lagi yang sifatnya preventif akan mengerucut pada pembatalan yang dilakukan oleh Presiden dengan instrumen Peraturan Presiden terhadap seluruh Perda dan Pembatalan yang dilakukan oleh mendagri terhadap Perda APBD, pajak daerah dan retribusi daerah serta tata ruang daerah kemudian ditambah dengan RPJPD, RPJMD serta pembatalan terhadap perda Kabupaten/Kota yang tidak dibatalkan oleh Gubernur dengan Permendagri pada UU No. 32 Thn 2004 yang sekarang pembatalannya menggunakan instrumen Keputusan Menteri Dalam Negeri sebagaimana yang diatur pada UU No. 23 Thn 2014. Tindakan hukum merupakan suatu tindakan yang dimaksudkan untuk menciptakan hak dan kewajiban. ${ }^{13}$

Tindak pemerintahan berdasarkan atas hukum adalah tindakan-tindakan yang mempunyai pengaruh hukum secara langsung, atau tindakan yang dimaksudkan untuk menimbulkan akibat hukum secara langsung. ${ }^{14}$ Pembatalan yang dilakukan oleh Presiden tersebut akan menimbulkan akibat hukum bahwa perda yang diajukan oleh Pemerintah Provinsi dan Pemerintah Kabupaten/Kota batal dan tidak memiliki kekuatan hukum yang mengikat dan Pemerintah Daerah harus mencabut dan tidak memberlakukan kembali perda yang dibatalkan tersebut. Mengingat eksekutif review berakhir pada keputusan yang diberikan oleh Presiden. Pembatalan yang

Ridwan, HR. 2011, Hukum Administrasi Negara, Raja Grafindo Persada, Jakarta, h.11.

14 I G. N. Wairocana, 2006, Tindak Pemerintahan (Suatu Orientasi Singkat, Fakultas Hukum Universitas Udayana, Denpasar, h. 7. dilakukan oleh Presiden ini juga dilakukan kepada Perda APBD, Pajak Daerah dan Retribusi Daerah dan Tata Ruang Daerah saat pemerintah daerah tidak menindak lanjuti hasil klarifikasi yang dilakukan oleh Mendagri serta tetap memberlakukan perda tersebut maka Mendagri akan memohonkan pembatalan yang ditujukan kepada Presiden untuk membatalkan Perda tersebut, hal ini diatur pada Pasal 95 ayat (1) Permendagri No. 1 Thn 2014.

Apabila Pemerintah Daerah bersikukuh untuk menolak keputusan pembatalan tersebut sebagaimana yang diatur pada Pasal 145 ayat (5) Apabila provinsi/kabupaten/kota tidak dapat menerima keputusan pembatalan Perda sebagaimana dimaksud pada ayat (3) dengan alasan yang dapat dibenarkan oleh peraturan perundang-undangan, kepala daerah dapat mengajukan keberatan kepada Mahkamah Agung.

Sementara pada UU No. 23 Thn 2014 Presiden hanya memiliki kewenangan untuk memberikan keputusan atas keberatan pembatalan Perda yang diajukan oleh Pemerintah Provinsi terhadap pembatalan yang dialakukan oleh mendagri. Sebagaimana diatur pada Pasal 251 ayat (7) Dalam hal penyelenggara Pemerintahan Daerah provinsi tidak dapat menerima keputusan pembatalan Perda Provinsi dan gubernur tidak dapat menerima keputusan pembatalan peraturan gubernur sebagaimana dimaksud pada ayat (4) dengan alasan yang dapat dibenarkan oleh ketentuan peraturan perundang-undangan, gubernur dapat mengajukan keberatan kepada Presiden 
paling lambat 14 (empat belas) Hari sejak keputusan pembatalan Perda atau peraturan gubernur diterima.

Pembatalan perda yang dilakukan oleh Mendagri yang sebelumnya pengaturannya pada UUNo. 32 Thn 2004 merupakan sematamata pembatalan Ranperda terhadap APBD, Pajak Daerah dan Retribusi Daerah dan Tata Ruang Daerah yang merupakan tahapan evaluasi dalam kaitannya melaksanakan pengawasan secara preventif sebagaimana yang diatur pada Pasal 185, memiliki kewenangan pembatalan pada tahapan klarifikasi yang merupakan pengasawasan secara represif terhadap Perda APBD, Pajak Daerah dan Retribusi Daerah dan Tata Ruang Daerah seperti yang diatur pada Pasal 90 ayat (3) dan (4) Permendagri No. 1 Thn 2014. Namun pembatalan yang mengacu pada Permendagri No. 1 Thn 2014 ini hanya sebatas jika Pemerintah Daerah mau mencabut dan tidak memberlakukan kembali Perda yang dibatalkan oleh Mendagri, tetapi jika Pemerintah Daerah tetap memberlakukan Perda yang dibatalkan tersebut sebagaimana yang diatur pada Permendagri tersebut Mendagri akan memohonkan pembatalan kepada Presiden untuk membatalkan Perda yang dibatalkan tersebut.

Diundangkannya UU No. 23 Thn 2014 menjadikan kewenangan Mendagri bertambah tidak hanya sebatas pada melakukan evaluasi Ranperda APBD, pajak daerah dan retribusi daerah serta tat ruang daerah yang sebelumnya diatur pada UU No. 32 Thn 2004 juga mencakup mengenai RPJPD dan RPJMD juga pembatalan Perda
Kabupaten/kota yang tidak dibatalkan oleh Gubernur dan keberatan Pemerintah daerah terhadap pembatalan perda yang dilakukan oleh Gubernur. Akibat hukum yang ditumbulkan yakni hanya menimbulkan pembatalan yang sifatnya tetap jika pemerintah daerah secara langsung untuk mencabut dan tidak lagi memberlakukan Perda yang dibatalkan oleh Mendagri, tetapi jika pemerintah daerah bersikukuh dan mengajukan keberatan kepada Presiden terhadap pembatalan Perda yang dilakukan oleh Mendagri Keputusan Pembatalan Mendagri tersebut bisa saja tidak berlaku apabila Presiden mengabulkan keberatan yang diajukan oleh Pemerintah Daerah. Mengingat keputusan Pembatalan Perda berada pada Presiden selaku Pemegang kekuasaan Pemerintah.

\section{PENUTUP}

\subsection{Simpulan}

1. Bahwa Pengaturan Pembatalan Perda yang dilakukan oleh Presiden dapat ditemukan pada Pasal 145 ayat (2) dan (3), UU No. 32 Thn 2004, Pasal 37 ayat (4) PP No. 79 Tahun 2005, serta Pasal 91 ayat (4) Permendagri No. 1 Tahun 2014, Pasal 251 ayat (7) UU No. 23 Thn 2014. Pengaturan Pembatalan perda yang dilakukan oleh Mendagri dapat ditemukan pada Pasal 185 ayat (5) UU No. 32 Thn 2004, Pasal 40 ayat (2) PP 79 Tahun 2005 dan Pasal 80 ayat (3) dan Pasal 90 ayat (3) Permendagri 1 Thn 2014, Pasal 245 ayat (1), Pasal 251 ayat (1), (3), (8), dengan diundangkannya UU No. 
23 Thn 2014 maka UU No. 32 Thn 2004 tidak berlaku kembali.

2. Bahwa akibat hukum yang ditimbulkan dengan Pembatalan yang dilakukan oleh Presiden adalah Pemerintah Daerah harus mencabut dan tidak memberlakukan kembali Perda yang telah dibatalkan tersebut atau ketika tidak setuju dengan pembatalan yang dilakukan oleh Presiden dapat mengajukan keberatan kepada Mahkamah Agung. Sementara bagi pembatalan yang dilakukan oleh Mendagri Perda yang dibatlakan tersebut dinyatakan tidak berlaku dan dicabut tetapi ketika Pemerintah daerah tidak mencabut dan tetap memberlakukan Perda yang dibatalkan tersebut perda tersebut masih berlaku sepnajang Presiden tidak memberikan keputusan pembtalan perda tersebut berdasarkan permohonan yang diajukan oleh Mendagri.

\subsection{Saran}

1. Agar seluruh ranperda tanpa terkecuali melalui tahapan evaluasi untuk diteliti apakah suatu ranperda yang akan dibentuk oleh Pemerintah Daerah terjadi pertentangan dengan peraturan perundang-undangan yang lebih tinggi dan/atau terjadi pertentangan dengan kepentingan umum sehingga menjadi jelas kewenangan Mendagri hanya terbatas pada proses preventif melalui tahap evaluasi dan pada proses represif tetap menjadi kewenangan Presiden selaku pemerintahan pusat dan pemegang kekuasaan Pemerintahan.

2. Agar dengan diberlakukannya UU No. 23 Thn 2014 Pemerintah lebih cepat untuk membentuk peraturan pelaksananya agar dapat melakukan penyesuaiaan serta dilakukan sosialisasi ke daerah guna daerah lebih cepat untuk beradaptasi sehingga tidak lagi menimbulkan kerancuan dan kebingungan mengingat induk dari pengaturan pemerintahan daerah telah diganti karena transisi dari UU No. 32 Tahun 2004 dan berubah ke UU No. 23 Thn 2014 akan memerlukan waktu meningat adanya perbedaan serta penambahan pengaturan baru yang mendasar tehadap pemerintahan daerah.

\section{DAFTAR PUSTAKA}

Asshiddiqie, Jimly, 2006, Hukum Acara Pengujian Undang-Undang, Konstitusi Press, Jakarta.

Ekathahjana, Widodo, 2008, Pengujian Peraturan Perundang-Undangan Dan Sistem Peradilannya di Indonesia, Pustaka Sutra, Jakarta.

Fajar, A. Muktie dan Yulianto Ahmad, 2009, Dualisme Penelitian Hukum Normatif dan Empiris, Pustaka Pelajar, Yogyakarta.

Fauzan, Muh, 2006, Hukum Pemerintahan Daerah Kajian Tentang Hubungan Keuangan Antara Pusat Dan Daerah, UII Press, Yogyakarta.

Indrohato, 1991, Usaha Memahami Undang-UndangTentang Peradilan tata Usaha Negara, Pustaka Sinar Harapan, Jakarta. 
(UDAYANA MASTER LAW JOURNAL)

Marburn SF., 1997, Peradilan

AdministrasiNegaradan UpayaAdministrasi

di Indonesia, Liberty, Yogyakarta.

Ridwan,HR. 2011,HukumAdministrasi Negara, Raja Grafindo Persada, Jakarta.

Soehino, 1991, Hukum Tata Negara PerkembanganOtonomiDaerah, Yogyakarta, Edisi Pertama, Cetakan Pertama, BPFE.

Soetjito, Irawan, 1993, Pengawasan terhadap Peraturan Daerah dan Keputusan Kepala Daerah, Bina Aksara, Jakarta.

Sutedi, Adrian, 2007, Implementasi Prinsip Kepentingan Umum Dalam Pengadaan Tanah Untuk Pembangunan, Sinar Grafika, Jakarta

Utama, I Made Arya, 2007, Hukum Lingkungan, Pustaka Sutra, Denpasar, h. 37. Wairocana, I G. N., 2006, Tindak Pemerintahan (Suatu Orientasi Singkat, Fakultas Hukum Universitas Udayana, Denpasar.

Widjaja, H. A. W., 2005, Penyelenggaraan Otonomi di Indonesia, Dalam Rangka Sosialisasi Undang-Undang No. 32 Tahun 2004 Tentang Pemerintahan Daerah, PT. Raja Grafindo Persada, Jakarta. 